\title{
Perceptual weighting of elevation localization cues across frequency
}

\author{
Ahrens, Axel; Brimijoin, Owen
}

Publication date:

2019

Document Version

Publisher's PDF, also known as Version of record

Link back to DTU Orbit

Citation (APA):

Ahrens, A., \& Brimijoin, O. (2019). Perceptual weighting of elevation localization cues across frequency. Poster session presented at 177th Meeting of the Acoustical Society of America, Louisville, Kentucky, United States.

\section{General rights}

Copyright and moral rights for the publications made accessible in the public portal are retained by the authors and/or other copyright owners and it is a condition of accessing publications that users recognise and abide by the legal requirements associated with these rights.

- Users may download and print one copy of any publication from the public portal for the purpose of private study or research.

- You may not further distribute the material or use it for any profit-making activity or commercial gain

- You may freely distribute the URL identifying the publication in the public portal

If you believe that this document breaches copyright please contact us providing details, and we will remove access to the work immediately and investigate your claim. 


\section{Introduction}

Much research has been conducted on the integration of information of binaural lateralization cues over frequency. Macpherson and Middlebrooks (2002) showed that fisteners weigh in in frequencies, while in tioural Ray

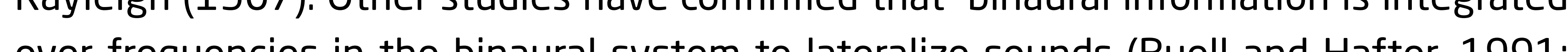

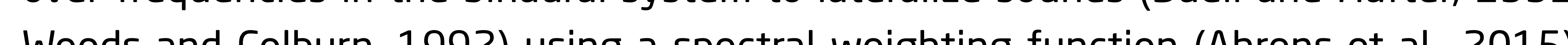

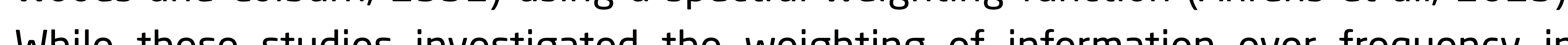
horizontal plane, no such weighting exists for vertical (elevation) localization.

In this study, we aimed to investigate if certain frequency areas are perceptually In this study, we aimed to investigate if certain frequency areas are perceptually
weighted higher than others. Furthermore, predictors of perceptual weights in the head-related transfer functions (HRTFs) were investigated.

\section{Methods}

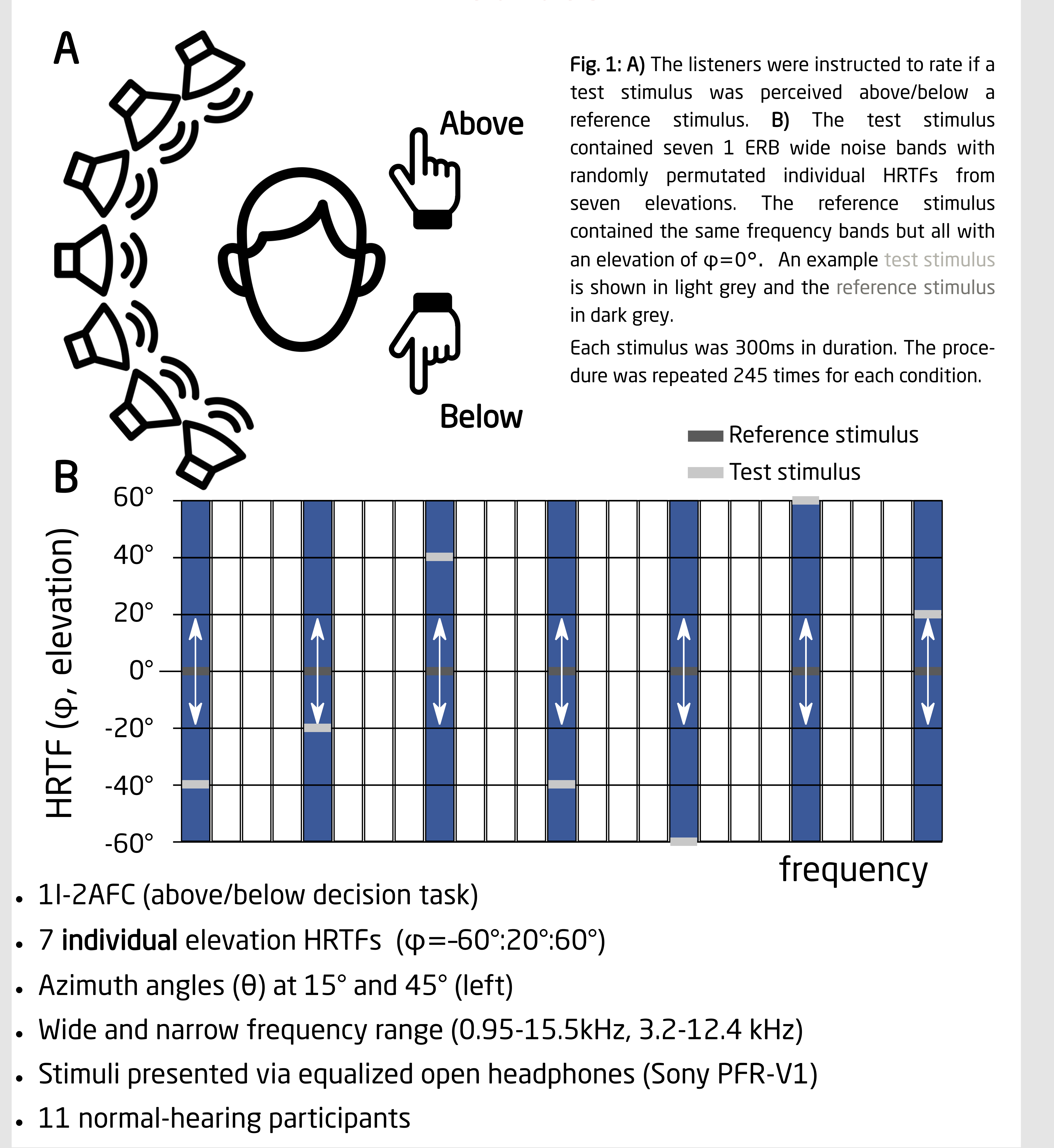

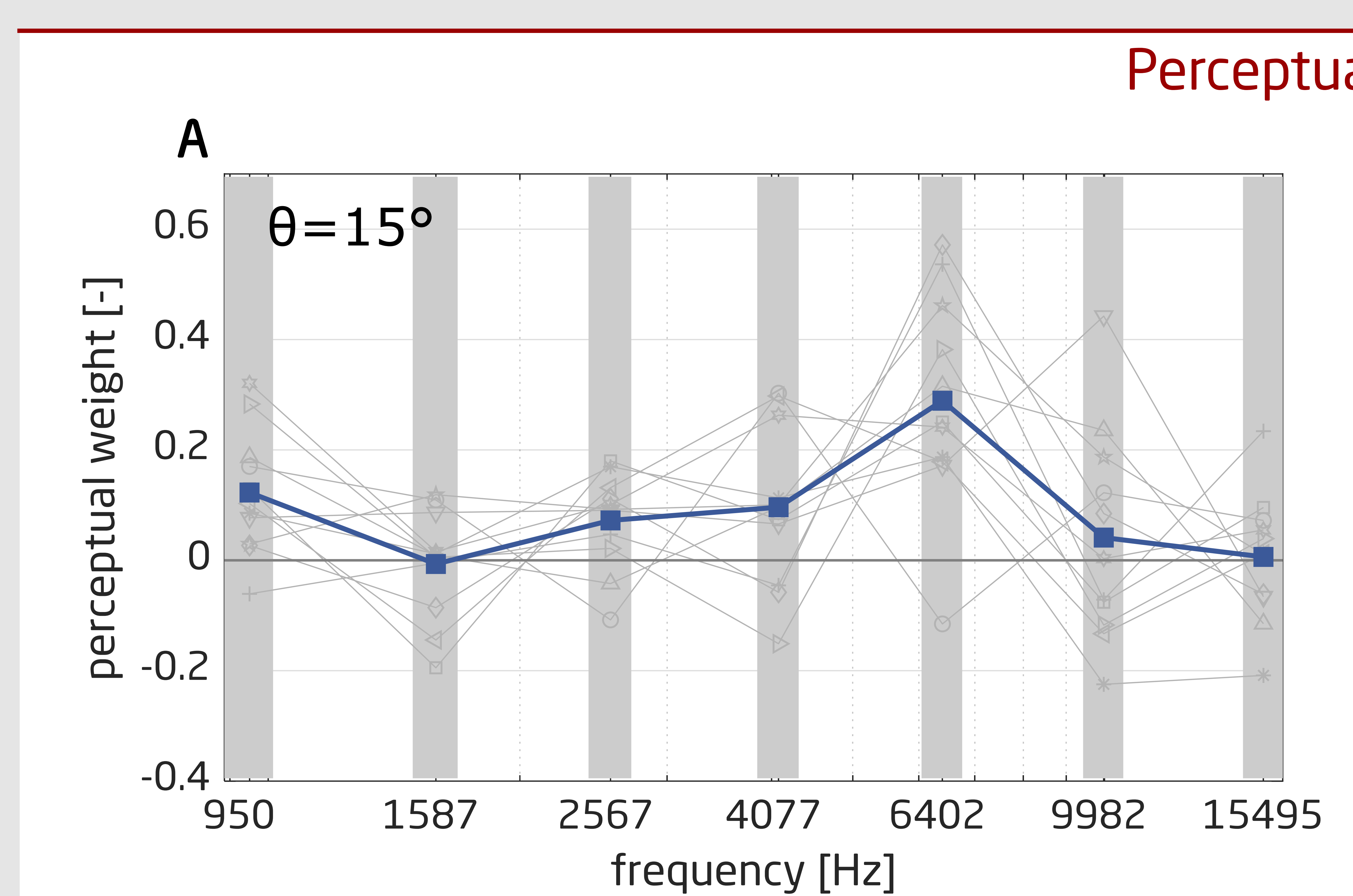

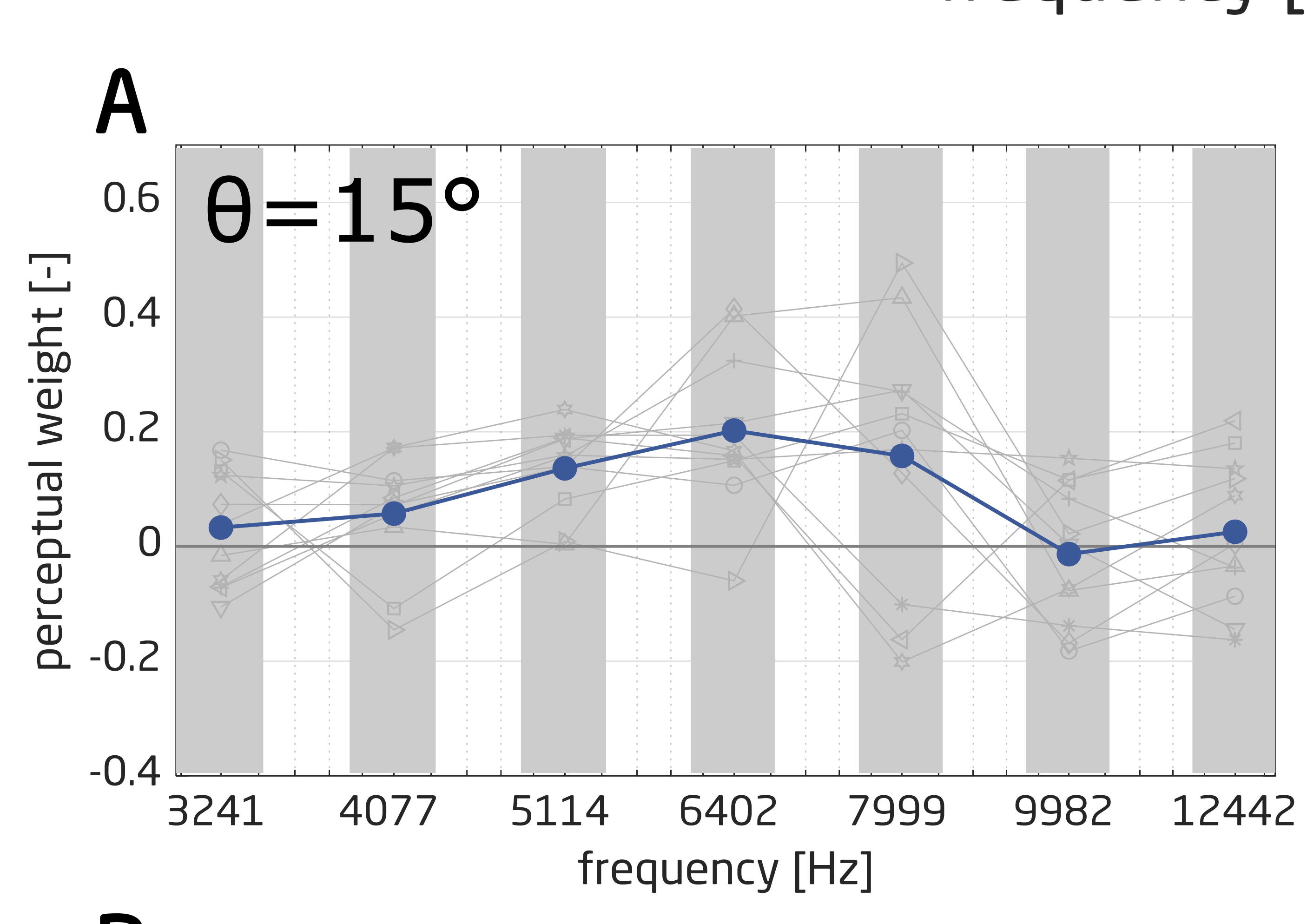

B

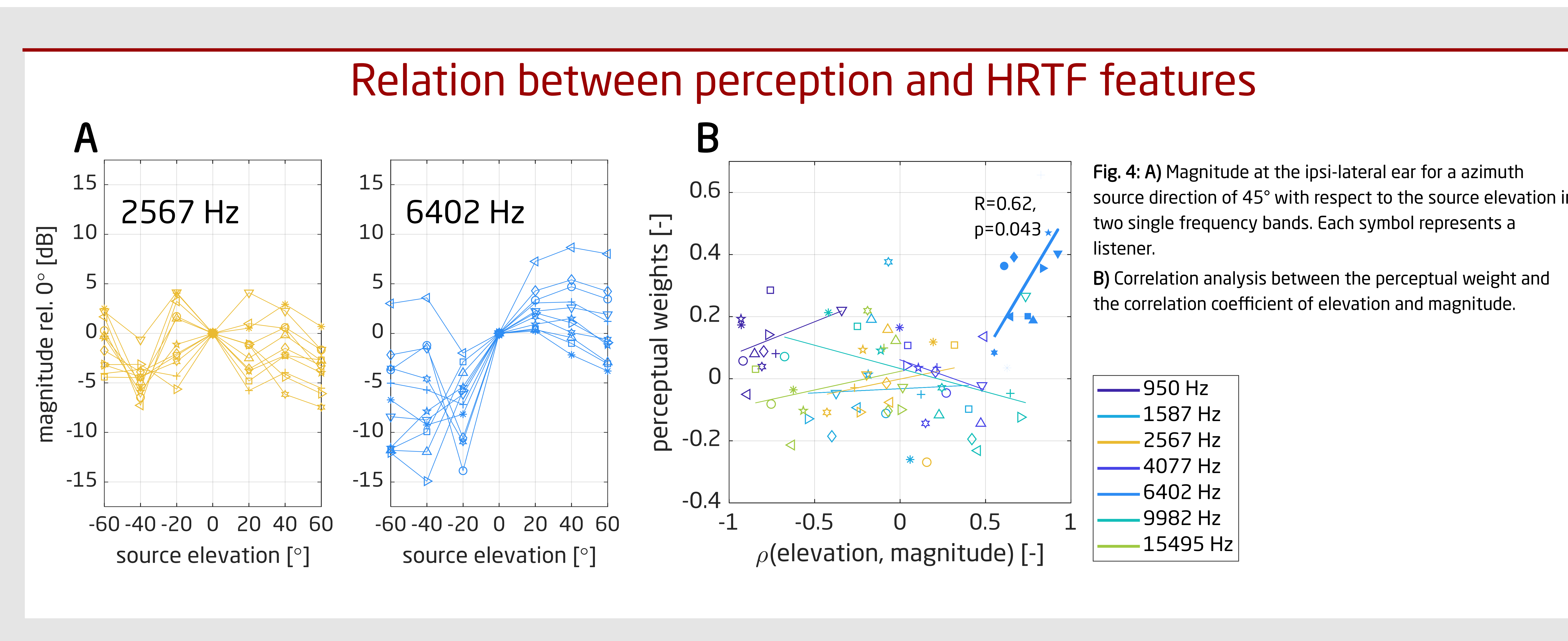

Discussion \& Conclusions

The frequency band of $6.4 \mathrm{kHz}$ is perceptually weighted largest with respect to elevation, however the intra-subject variation is large The magnitude variation predictability over the elevations of the individual HRTFs correlates with the perceptual weights A narrow frequency range seems to lead to less reliable perceptual weighting results Results are a perceptual extension to directional/boosted bands (Blauert, 1997)

Step towards a weighting function for computational models (e.g. Zonooz et al., 2019) 